\title{
Marginal bone loss around dental implants with conical and hexagonal implant-abutment interface: A literature review
}

\section{Utrata kości wokół implantów z łącznikiem stożkowym lub heksagonalnym - przegląd piśmiennictwa}

\author{
Jolanta Szymańska ${ }^{1,(-F}$, Piotr Szpak²,A-D \\ ${ }^{1}$ Department of Paedodontics, Medical University of Lublin, Lublin, Poland \\ 2 Individual Dental Practice "Dentistry Implantology Piotr Szpak", Białystok, Poland \\ A - research concept and design; $B$ - collection and/or assembly of data; $C$ - data analysis and interpretation; \\ $D$ - writing the article; $E$ - critical revision of the article; $F$ - final approval of article
}

Address for correspondence

Jolanta Szymańska

E-mail: szymanska.polska@gmail.com

Funding sources

none declared

Conflict of interest

none declared

Received on February 19, 2017

Revised on March 18, 2017

Accepted on May 28, 2017

\begin{abstract}
Based on a review of topical literature, the paper presents the results of studies concerning marginal bone loss around dental implants. The paper provides a detailed description of the process of bone loss around dental implants with conical implant-abutment connection generally used in implant prosthetic treatment. The reviewed articles reported experimental studies involving animals, as well as clinical research in humans. The results concerning bone loss around the hexagonal implant-abutment interface are cited only to provide the historical background, as implants with internal connections are generally available and currently used in oral implantology. The research on bone loss around implants conducted over the years has allowed for the assessment of the relationships between various factors that may affect the process of bone loss around implants and, consequently, influence the final result of the treatment and therapeutic success. The researchers focused on the effect of such factors as: differences in implant structure, types of surfaces, shapes and materials. In addition, bone loss is dependent on prosthetic treatment: implants may be placed at different locations in the alveolar process bone and at different levels in the hard bone; open or closed methods of healing are used; types of prosthetic restorations loaded after implantation vary, as also varies the time from implantation to loading (early or late loading), types of cementing material and cementing techniques. The paper discusses also the presence of a microgap and its colonization by microorganisms as factors that negatively affect the process of osseointegration.
\end{abstract}

Key words: dental implants, marginal bone loss, abutment type

Słowa kluczowe: implanty stomatologiczne, utrata kości, typ łącznika

DOI

$10.17219 / \mathrm{dmp} / 74143$

Copyright

○ 2017 by Wroclaw Medical University

and Polish Dental Society

This is an article distributed under the terms of the

Creative Commons Attribution Non-Commercial License

(http://creativecommons.org/licenses/by-nc-nd/4.0/) 
Identifying the factors affecting dental implant survival and the results of treatment with this method at each stage of the therapy may be helpful in attaining therapeutic success. One of the success criteria is the level of marginal bone loss around an implant, observable in radiographs. ${ }^{1}$ The results of long-standing observations, conducted from the moment the dental implants had been first used, detected a continuing tendency for peri-implant bone loss, regardless of the implant type and other factors. As early as in 1986, Albrektsson et al. ${ }^{2}$ estimated the average bone loss, progressing in time, around the implants. They assumed that the average loss of marginal bone should not exceed $1.5 \mathrm{~mm}$ during the first year after implantation, and $0.2 \mathrm{~mm}$ per year in the consecutive years. The cited bone loss values were based on the study of dental implant systems used in 1980s. Bone loss occurs for most implant systems, but its extent varies. It was found that a great influence on marginal bone loss around the implant neck is exerted by microgaps at the level of implant-abutment connection that are responsible for micromovements. The microgaps create bacterial micropumps that allow bacteria to permeate into the connection and out of it, causing inflammation around implants, thus leading to marginal bone loss. ${ }^{3-5}$

The paper focuses on a presentation of the results of studies on peri-implant marginal bone loss, with special emphasis on the implant systems with the conical implant-abutment interface. The results concerning bone loss around the hexagonal implant-abutment interface are cited only to provide the historical background, as implants with internal connections are generally available and currently used in oral implantology.

\section{Marginal bone loss around implants in experimental studies involving animals}

The results of the studies in canines published in 2002 showed that 2 months after implantation marginal bone loss around implants with welded abutments (no microgap) differed significantly from that around implants with non-welded abutments (gaps of different sizes: <10, 50, and $100 \mu \mathrm{m}$ ), but the size of a microgap did not affect the bone loss intensity. In the $3^{\text {rd }}$ month, however, there were no statistically significant differences between the two studied groups $(\mathrm{p}>0.7){ }^{6}$

Weng et al. made a comparison of 2 dental implant systems: DENTSPLY Friadent ANKYLOS ${ }^{\circledR}$ with a conical implant-abutment connection and Nobel Biocare Brånemark System TiUnite ${ }^{\circledR}$ with an external hexagonal connection. ${ }^{7}$ In their experiment with dogs, the researchers evaluated marginal bone loss, as well as the first bone-toimplant contact. Implant healing with a closed method lasted 3 months, while for another 3 months the implants, provided with healing abutments, were maintained with- out functional load. After 6 months, for the equicrestally placed implants, the bone level around ANKYLOS implants was $0.69 \mathrm{~mm}$, while that around TiUnite ones was $0.91 \mathrm{~mm}$. The difference between the 2 implant types was not statistically significant. When implants were inserted $1.5 \mathrm{~mm}$ below the bone crest, the difference between the systems was twofold ( 0.90 vs $0.42 \mathrm{~mm}$ ), and the better result was obtained for ANKYLOS; the difference, however, was statistically non-significant. At the same time, bone formation at the edge of the submerged implant neck was found at the implant-abutment connection.

In a later work, Weng et al. presented the results of their experiment, also in dogs, where they used an open method of implant healing (with functionally unloaded abutments); they tested, as previously, ANKYLOS and TiUnite. After 3 months of healing from submerged implants, marginal bone loss was $1.56 \mathrm{~mm}$ for TiUnite, and $0.79 \mathrm{~mm}$ for ANKYLOS ( $p>0.05) .{ }^{8}$ After a 3-month observation no significant changes in the marginal bone level around ANKYLOS implants were found, while for TiUnite significant marginal bone loss was observed as early as 1 month after implantation. Marginal bone loss around implants was lower in the case of non-submerged implants: after 3 months it reached $0.69 \mathrm{~mm}$ for TiUnite, and $0.48 \mathrm{~mm}$ for ANKYLOS ( $\mathrm{p}>0.05$ ). For TiUnite implants, significant bone loss was observed after only 2 months, while in the case of ANKYLOS implants, the perimplant marginal bone level did not change significantly over 3 months. Those results show that implants with external hexagonal abutments (Nobel Biocare Brånemark System TiUnite), i.e. those with microgaps and micromovements, when placed subcrestally, contribute to greater bone loss in comparison to implants with conical implant-abutment interface (DENTSPLY Friadent ANKYLOS).

In a study involving monkeys, ANKYLOS system with conical implant-abutment connection was compared to a system with internal hexagonal connection. The study evaluated the status of peri-implant tissues: the probing pocket depth, probing pocket loss, and the width of keratinized mucosa, as well as implant osseointegration (measured with Priotest ${ }^{\circledR}$ device). The mucogingival response and Priotest values estimated after 3 and 6 months of observation pointed to ANKYLOS as a better system. ${ }^{9}$

The process of osseointegration for implants with immediate prosthetic load was evaluated with an experimental study also in monkeys. ANKYLOS implants placed in the posterior part of the mandible and subjected to immediate loading became osseointegrated in a similar way as implants with delayed loading. In addition, immediate loading increased the degree of implant integration with the bone, which could be observed as higher bone density among the threads of the implants. The mean BIC (boneto-implant contact) value was $64.25 \%$ in the group with immediately loaded implants, and $67.93 \%$ in the group with delayed loaded implants, but the differences were not statistically significant $(\mathrm{p}=0.656) .{ }^{10}$ 


\section{The status of marginal bone around implants according to the type of implant-abutment interface}

The present-day studies on implants aim at designing an ideal interface between abutment and implant. There is a wide variety of kinds/types of implant-abutment connections. The connections may be flexible or rigid. Among the most commonly used rigid ones, internal and external connections can be distinguished. The connections may also be of different shapes: polygonal (triangular, hexagonal, octagonal, and other modifications of polygonal shapes) and conical (cones of varying angles and Morse taper). Abutments are made of titanium, ceramic material or zirconium oxide. ${ }^{11}$

\section{Marginal bone around an implant with conical implant-abutment}

The results of 18-month observation of 1,419 implants (DENTSPLY Friadent ANKYLOS) in 313 patients were published in 2001. The data was obtained from 100 dental surgeons working at 32 clinical centers in USA, Korea and Taiwan. The study showed that 1 year after loading with prosthetic replacements, marginal bone loss around the studied implants was $0.2-0.5 \mathrm{~mm} .{ }^{12}$

Another multicenter study involving 1,500 ANKYLOS implants found that the bone loss that occurred between the time of implant placement and loading was $0.81 \mathrm{~mm}$. The bone loss between the implant placement and uncovering reached $0.70 \mathrm{~mm}$, while between uncovering and loading - $0.11 \mathrm{~mm}$. Marginal bone loss after 12 months from loading was $0.15 \mathrm{~mm}$, after 24 months $-0.48 \mathrm{~mm}$, and after 36 months $-0.64 \mathrm{~mm}(0.16 \mathrm{~mm}$ per year). The total average bone loss from the time of implant placement to 36 months after loading was $0.60 \mathrm{~mm}$ ( $0.20 \mathrm{~mm}$ per year); the obtained value was lower than for other implant systems. The extent of marginal bone loss did not depend on age, gender, type of prosthetic application or tobacco smoking. ${ }^{13}$

In several papers, Mangano et al. presented the results of their evaluation of marginal bone loss around Morse taper connection implants (Leone ${ }^{\circledR}$ Implant System). ${ }^{14-18}$ During a 4-year observation, the researchers used a dental probe ${ }^{14}$ and pantomographic radiographs. ${ }^{15}$ Twelve months after the time of loading, bone loss did not exceed $1.5 \mathrm{~mm}$ and progressed by only $0.22 \mathrm{~mm}$ per year. ${ }^{15}$ In the case of implants loaded with a single crown, bone loss was $0.88 \mathrm{~mm} .{ }^{16}$ After 4 years of functional loading of implants with single crowns, marginal bone loss was $1.14 \mathrm{~mm},{ }^{14}$ while after 6 years of loading 2,549 implants with various types of prosthetic restorations, bone loss reached $1.10 \mathrm{~mm}( \pm 0.30 \mathrm{~mm}) .{ }^{17}$ The study covering 288 implants in 6 patients 5 years after loading with bar-retained overdentures (38 in the maxilla and 34 in the mandible) showed that marginal bone loss did not exceed $0.7 \mathrm{~mm} .{ }^{18}$
The fact that conical construction of implant-abutment connection does not create adverse conditions for osseointegration was confirmed in 50 patients with 69 ANKYLOS implants placed in a subcrestal position and healed with the open method and non-functional loading. After a 14-month observation (within a 9-20 month interval) no correlation was found between the level of implant position below the bony crest and marginal bone loss $(\mathrm{r}=0.15, \mathrm{p}>0.05)$. However, a correlation was detected $(\mathrm{r}=0.21, \mathrm{p}<0.05)$ between the implantation depth and the presence of hard tissue at the edges and platform of implants, which indicated the conditions that favored contact and bone growth at the implant-neck side. ${ }^{19}$

An earlier study showed that after immediate loading, out of occlusal contact, of Straumann ${ }^{\circledR}$ implants with conical connection, marginal bone loss around implants was the same as in the case of early loaded implants, also out of occlusal contact (loaded 28-34 days after the surgery). Twelve months after prosthetic loading of 383 implants (197 immediately loaded and 186 early loaded), bone loss was $0.77 \mathrm{~mm}( \pm 0.93 \mathrm{~mm})$. This shows that the conical implant-abutment connection allows loading at varying times with the same clinical outcome. ${ }^{20}$

\section{Marginal bone loss around implants with internal polygonal implant-abutment connection}

The assessment of the efficacy of BIOMET ${ }^{\circledR} 3 \mathrm{i}$ system, based on the observation of 1,583 implants (loaded with different types of prosthetic solutions) placed in 528 patients from 13 European clinical centers, showed that periimplant marginal bone loss after 6 months was $0.04 \mathrm{~mm}$ $( \pm 1.3 \mathrm{~mm})$, after 12 months $-0.12 \mathrm{~mm}( \pm 1.6 \mathrm{~mm})$, and after 24 months $-0.2 \mathrm{~mm}( \pm 1.7 \mathrm{~mm}) .^{21}$

Marginal bone loss of $1.7 \mathrm{~mm}( \pm 0.88)$ (from $0.8-5 \mathrm{~mm}$ ) was found after 22 years (mean 18.4 years) from the moment of treatment with Nobel Biocare Brånemark System implants. Bone loss increased between the $1^{\text {st }}$ and the $4^{\text {th }}$ year of observation, while after this period bone loss did not change. ${ }^{22}$

Bone loss of $0.77 \mathrm{~mm}$ (flap approach) and $1.43 \mathrm{~mm}$ (flapless method) was found after the placement of 147 implants of a Polish system Osteoplant ${ }^{\circledR}$ Hex. ${ }^{23}$ Ricci et al. report that the examination of 51 patients with 112 DENTSPLY Friadent Frialit ${ }^{\mathbb{R}}-2$ implants with internal hexagonal connection, after 5 years of loading with prosthetic restorations, showed $2.17 \mathrm{~mm}( \pm 1.6 \mathrm{~mm}) .^{24}$ The results of observing the same Frialit-2 system implants, conducted for 6-60 months (mean observation time 33.45 months), showed $0.27 \mathrm{~mm}$ marginal bone loss around implants with switched platforms (the diameter of connections was smaller than the diameter of implants at implant-abutment connections), while in the group of implants without platform switching, bone loss was $2.30 \mathrm{~mm}$. It was emphasized that moving the microgap inward from the outer edge of platform-switched implants reduces marginal bone loss. ${ }^{25}$ 
A complete elimination of the problem related to the connection between the implant and the superstructure was presented earlier in a study on Cresco $^{\mathrm{TM}}$ implants with an octagonal connection placed using the specific Precision ${ }^{\circledR}$ Method. This method involves soldering an implant-supported prosthetic superstructure to create passively fitting constructions, free from tensions that may sometimes occur in the case of structures cast as a whole. Bone loss found in this study after 12 months was $0.11 \mathrm{~mm}$, and after 60 months $-0.3 \mathrm{~mm} .^{26}$

Implants with a hexagonal internal implant-abutment connection, manufactured by MIS Implants Technologies Ltd, are widely used, and consequently numerous reports on the results of treatment with MIS $^{\circledR}$ implants are available. In 2006, Tandlich et al. published the results of the therapy with 181 MIS implants with internal hexagonal connection observed from 30 months to 9 years after implantation (mean observation time 5.3 years). ${ }^{27}$ The average bone loss was $2.99 \mathrm{~mm}$. Using an individual implant as the unit of analysis, the researchers found that factors correlated with higher bone loss included the time from implantation $(p=0.03)$, tobacco smoking and the presence of a removable prosthesis $(p<0.05)$. In the following year, the same scholars published the results of their evaluation of the influence exerted by removable prostheses based on MIS implants on implant survival rate and marginal bone loss. Eighty-two patients were fitted with 265 MIS implants, of which $95.8 \%$ survived. Odds ratios for higher rates of marginal bone loss were 1.95 for smokers, and 2.57 for patients with removable prostheses. ${ }^{28}$ Evaluation of marginal bone loss around 294 MIS implants with internal hexagonal connection between 22 and 59 month after implantation (mean observation time 38 months) found 0.33 -mm marginal bone loss one year after prosthetic loading of implants. ${ }^{29}$

\section{Microgaps and micromovements in the connections at the implant-abutment level in various implant systems}

\section{The presence of microgaps and micromovements in implant systems}

The above-cited results of studies in dogs show that the absence of microgaps was a decisive factor that affected marginal bone loss. At the same time, the size of microgaps did not influence peri-implant bone loss $(\mathrm{p}>0.7) .^{6}$

The role of microgaps at the implant-abutmment level was also examined. The study involving ANKYLOS with a conical Morse connection and Nobel Biocare Brånemark System TiUnite with hexagonal external implant-abutment connection found that plate-like marginal bone loss around implants was caused by microbiologically contami- nated microgaps at the implant abutment level, mechanically loaded with a prosthetic restoration. ${ }^{5}$ A little later, Weng et al., comparing two implant systems (ANKYLOS and TiUnite) in the above-cited studies involving dogs, found that different types of implant-abutment connection may affect the level of marginal bone around implants already at the stage of closed healing (up to 6 months of observation). ${ }^{7}$ In the case of a conical implant-abutment connection, a tendency towards smaller bone loss was found, while bone overgrowth at the edge of implant neck was observed directly at the implant-abutment connection. ${ }^{7}$

The problem of microgaps was addressed in 2004 by Weigl, who presented the advantages and functions of ANKYLOS implants used in restoration of single missing teeth with crowns. ${ }^{30}$ He found that only $1.3 \%$ of 233 implants showed loosened abutments after the mean observation period of 6.3 years. Zipprich et al., however, published in 2007 a paper dedicated to micromovements in implant-abutment connections in various implant systems. ${ }^{31}$ They detected different sizes of microgaps in the studied implant systems. Microgaps were absent in two systems: ANKYLOS and Astra Tech Implant System ${ }^{\mathrm{TM}}$, while micromovements were found in other systems, such as: $\mathrm{SIC}^{\circledR}$, Replace Select ${ }^{\circledR}$, Camlog $^{\circledR}$, Xive ${ }^{\circledR}$, Straumann-synOkta ${ }^{\circledR}$ und Fräszylinder ${ }^{\circledR}$, Bego-Semados $^{\circledR}$, and Straumann-Massivsekundärteil ${ }^{\mathbb{R}}$. In earlier studies, the same authors, evaluating the implantabutment connection in ANKYLOS, after 1,000,00 cycles of machine simulation of the chewing forces affecting prosthetically loaded implants in the oral cavity, did not find either material wear or micromovements. ${ }^{32}$

The function of implant-abutment connection depends to a large extent on the material of which they are manufactured. A microgap found in DENTSPLAY DeguDent Cer$\operatorname{con}^{\circledR}$ abutments was smaller than that in titanium ones. ${ }^{33}$

\section{Bacterial colonization of microgaps in implant-abutment connections}

The problem of microgaps is closely related to the problem of their colonization by bacteria that create particularly adverse conditions for implant osseointegration.

Assenza et al., evaluating in vitro bacteria migration from the inside to the outside of implant-abutment connection in 3 types of connections without prosthetic loading, detected bacteria in 6 out of 10 implants with trilobe connections, and only in 1 out of 10 implants with conical connections. ${ }^{3}$ Bacteria were not found in implants with cemented connections.

Earlier studies evaluated the colonization of implant-abutment connection with bacteria Aggregatibacter actinomycetemcomitans and Porphyromonas gingivalis. The connection types in the studied implant systems were the following: standard Morse taper, Morse taper with a $0.5-\mathrm{mm}$ groove modification, and tri-channel internal connection. It was shown that only 3 out of 10 examined unmodified conical connections were colonized by bac- 
teria, while in the case of connections with a groove connection, colonization was detected in 9 out of 10 implants and in 10 out of 10 implants with tri-channel connections. Thus, only the standard Morse taper guaranteed protection against bacterial colonization. ${ }^{34}$

The susceptibility of conical connection to the colonization by Escherichia coli bacteria was assessed by Koutouzis et al. ${ }^{4}$ The evaluation of bacterial colonization inside implants involved standard abutments with Morse taper and modified, four-groove abutments, also with Morse taper. The examination showed that 1 out of 14 implants with standard connection was infected with bacteria, while as many as 12 out of 14 implants with modified abutments were internally infected. The cited study confirmed that Morse conical connection is bacteria-tight.

In the case of conical connection, bacteria did not permeate either from the inside of implants to the outside, or from the external environment into implants, which was shown by Dibart et al., who studied 25 implants in vitro. ${ }^{35}$

The problem of adverse influence of bacteria around an implant results not only from the presence of bacteriacolonized microgaps, but is also due to the procedure of cementing prosthetic restorations. The correct cementing of prosthetic restoration should prevent bacterial leakage at implant fixture-abutment interface. Piwowarczyk et al., studying bacterial leakage after using various types of cements, found that, although none of the tested materials prevented bacterial microleakage at crown-abutment connection, the cement manufactured by 3M ESPE - RelyX Unicem $^{\mathrm{TM}}$ proved the best one. ${ }^{36}$ The authors emphasize that the results of implant treatment are not only affected by the tightness of implant-abutment connection (which depends on its construction), the kind of cementing material, but also by the cementing technique.

\section{Marginal bone around different types of implants in the same patient}

The assessment of the status of marginal bone around the implant during the processes of implant therapy was addressed in numerous studies. However, almost all of those papers reported research on a group of patients treated with the same type of implants, while only a few articles described different types of implants in the same patient. It must be noted that in such circumstances a comparison of treatment results is difficult because of individual differences that cannot be eliminated either by studies on large populations or by multifactorial statistical analysis of the collected data.

An instance of observation of patients with one of the two types of implants was reported in the paper by Pieri et al., 37 who described 0.51-mm marginal bone loss around implants with internal hexagonal implant-abutment connection, and $0.22-\mathrm{mm}$ around implants with a conical one $(\mathrm{p}=0.004), 12$ months after immediate loading with prosthetic restorations. In addition, the researchers found that between the two groups, there were no significant differences concerning such periodontal parameters as marginal soft tissue level and papilla height ( $\mathrm{p}>0.05)$.

A study by Degidi et al. is one of the few works that report on a histological and histomorphometric evaluation of the progress of osseointegration around implants in a bone sample, taken from humans, with two implant systems. ${ }^{38}$ The patients received two ANKYLOS implants and two BIOMET implants with platform-switching. The BIOMET implants were inserted $1 \mathrm{~mm}$ below the bone crest, while the ANKYLOS $-3 \mathrm{~mm}$ below the crest. The implants were immediately restored with screwed-on splinted connections. After 6 weeks of healing, one implant was surgically retrieved from each system. It was found that the first bone-to-implant contact was $0.1-0.3 \mathrm{~mm}$ below the implant neck for ANKYLOS, while for BIOMET it was $0.7 \mathrm{~mm}$ below the neck. No symptoms of soft tissue inflammation were found for either implant type.

Bratu et al. published two papers on marginal bone loss around implants with internal hexagonal connection, but with two types of implant neck surface, placed in the same patient. ${ }^{39,40}$ The study published in $2007^{39}$ compared bone loss around 72 implants of two MIS subsystems. It was found that after 4 months of healing, bone loss around Lance ${ }^{\circledR}$ implants (L-model with a polished neck) was $0.91 \mathrm{~mm}$, while around Seven ${ }^{\circledR}$ implants (S-model with microthreads) $-0.22 \mathrm{~mm}$. After 6 months of loading with a prosthetic restoration bone loss reached $1.29 \mathrm{~mm}$ for Lance subsystem, and $0.65 \mathrm{~mm}$ for Seven subsystem, while after 12 months it was $1.47 \mathrm{~mm}$ and $0.68 \mathrm{~mm}$, respectively. Another paper by Bratu et al. compared the two MIS implants subsystems: S-model and L-model in 46 patients, on the basis of pantomographic radiograms made immediately after crown cementation on implants abutments, after 6 and 12 months. ${ }^{40}$ The study found that bone loss was significantly lower for S-model than for L-model, and reached, respectively: $0.21 \mathrm{~mm}$ and $0.77 \mathrm{~mm}$ immediately after cementation, $0.56 \mathrm{~mm}$ and $1.20 \mathrm{~mm}$ after 6 months, and $0.69 \mathrm{~mm}$ and $1.47 \mathrm{~mm}$ after 12 months. The results of those studies show the significance of implant surface modification for osseointegration process.

\section{Conclusions}

The presented review of available literature shows that the marginal bone loss around the implant systems with the conical implant-abutment interface is so slight that it is conducive to positive treatment results and therapeutic success. Undoubtedly, however, it is also dependent on the influence of numerous other factors. Firstly, the factors in question are related to the implant system: differences in implant structure, types of surfaces, shapes and materials. Secondly, bone loss depends on prosthetic treatment: 
implants may be placed at different locations in the alveolar process bone and at different levels in the hard bone; open or closed methods of healing are used; types of prosthetic restorations loaded after implantation vary, as also varies the time from implantation to loading (early or late loading), types of cementing material and cementing techniques. As the cited studies show, the patient's characteristics, such as age, gender and tobacco smoking, also affect marginal bone loss around dental implants.

\section{References}

1. Papaspyridakos P, Chen JC, Singh M, Weber HP, Gallucci GO. Success criteria in implant dentistry: A systematic review. J Dent Res. 2012;91:242-248.

2. Albrektsson T, Zarb G, Worthington P, Ericksson AR. The long-term efficiency of currently used dental implants: A review and proposed criteria of success. Int J Oral Maxillofac Implants, 1986;1:11-25.

3. Assenza B, Tripodi D, Scarano A, Perrotti V, Piattelli A, lezzi G. Bacterial leakage in implants with different implant-abutment connections: an in vitro study. J Periodontol. 2012;83:491-497.

4. Koutouzis T, Wallet S, Calderon N, Lundgren T. Bacterial colonization of the implant-abutment interface using an in vitro dynamic loading model. J Periodontol. 2011:82:613-618.

5. Weng D, Richter EJ. Die Implantat-Abutment-Verbindung - Vom mechanischen zum biologischen Aspekt des Mikrospalts. Implantologie. 2005;13:125-130 [in German].

6. King GN, Hermann JS, Schoolfield JD, Buser D, Cochran DL. Influence of the size of the microgap on crestal bone levels in non-submerged dental implants: A radiographic study in the canine mandible. J Periodontol. 2002;73:1111-1117.

7. Weng D, Nagata MJ, Bell M, Bosco AF, de Melo LG, Richter EJ. Influence of microgap location and configuration on the peri-implant bone morphology in submerged implants. An experimental study in dogs. Clin Oral Implants Res. 2008;19:1141-1147

8. Weng D, Nagata MJ, Leite CM, de Melo LG, Bosco AF. Influence of microgap location and configuration on radiographic bone loss in nonsubmerged implants: an experimental study in dogs. Int $J$ Prosthodont. 2012;24:445-452.

9. Taiyeb-Ali TB, Toh ChG, Siar ChH, Seiz D, Ong ST. Influence of abutment design on clinical status of peri-implant tissues. Implant Dentistry. Int J Oral Implantol. 2009;18:438-446.

10. Romanos GE, Toh CG, Siar CH, Swaminathan D. Histologic and histomorphometric evaluation of peri-implant bone subjected to immediate loading: An experimental study with Macaca fascicularis. Int J Oral Maxillofac Implants. 2002;17:44-51.

11. Majewski S. ed.: Implantology. Seria Stomatologia Praktyczna. Wrocław: Elsevier Urban\&Partner, 2007 [in Polish].

12. Morris HF, Winkler S, Ochi S, Kanaan A. A new implant designed to maximize contact with trabecular bone: survival to 18 months. J Oral Implantol. 2001;27:164-173.

13. Chou CT, Morris HF, Ochi S, Walker L, DesRosiers D. AICRG, Part II: Crestal bone loss associated with the ANKYLOS implant: loading to 36 months. J Oral Implantol. 2004;30:134-143.

14. Mangano C, Mangano F, Piattelli A, lezzi G, Mangano A, La Colla L. Prospective clinical evaluation of 307 single-tooth Morse taperconnection implants: A multicenter study. Int J Oral Maxillofac Implants, 2010;25:394-400.

15. Mangano C, Mangano F, Piattelli A, lezzi G, Mangano A, La Colla L. Prospective clinical evaluation of 1920 Morse taper connection implants: Results after 4 years of functional loading. Clin Oral Implants Res. 2009;20:254-261.

16. Mangano C, Mangano F, Piattelli A, Lezzi G, Mangano A, La Colla L. Single-tooth Morse taper connection implants after 1 year of functional loading: A multicentre study on 302 patients. Eur J Oral Implantol. 2008;1:305-315.

17. Mangano C, Mangano F, Shibli JA, Tettamanti L, Figliuzzi $M$, d'Avila S. Prospective evaluation of 2,549 Morse taper connection implants: 1- to 6-year data. J Periodontol. 2011;82:52-61.
18. Mangano C, Mangano F, Shibli JA, Ricci M, Sammons RL, Figliuzzi M. Morse taper connection implants supporting "planned" maxillary and mandibular bar-retained overdentures: A 5-year prospective multicenter study. Clin Oral Implants Res. 2011;22:1117-1124.

19. Donovan R, Fetner A, Koutouzis T, Lundgren T. Crestal bone changes around implants with reduced abutment diameter placed nonsubmerged and at subcrestal positions: A 1-year radiographic evaluation. J Periodontol. 2010;81:428-434.

20. Ganeles J, Zöllner A, Jackowski J, ten Bruggenkate C, Beagle J, Guerra F. Immediate and early loading of Straumann implants with a chemically modified surface (SLActive) in the posterior mandible and maxilla: 1-year results from a prospective multicenter study. Clin Oral Implants Res. 2008;19:1119-1128.

21. Davarpanah $M$, Martinez $H$, Etienne $D$, Zabalegui I, Mattout $P$, Chiche F. A prospective multicenter evaluation of 1,583 3i implants: 1- to 5-year data. Int J Oral Maxillofac Implants, 2002;17:820-828.

22. Dierens M, Vandeweghe S, Kisch J, Nilner K, De Bruyn H. Longterm follow-up of turned single implants placed in periodontally healthy patients after 16-22 years: radiographic and peri-implant outcome. Clin Oral Implants Res. 2012;23:197-204.

23. Kukuła J, Sidorowicz K, Sokalski J. The evaluation of the marginal bone loss in traditional and flapless approach of Osteoplant Hex implants. Implantoprot. 2007;26-27:15-19 [in Polish].

24. Ricci G, Aimetti M, Stablum W, Guasti A. Crestal bone resorption 5 years after implant loading: clinical and radiologic results with a 2-stage implant system. Int J Oral Maxillofac Implants, 2004;19:597-602.

25. De Almeida FD, Carvalho AC, Fontes M, Pedrosa A, Costa A, Noleto JW. Radiographic evaluation of marginal bone level around internal-hex implants with switched platform: A clinical case report series. Int J Oral Maxillofac Implants. 2011;26:587-592

26. Helldén L, Ericson G, Elliot A, Fornell J, Holmgren K, Nilner K. A prospective 5-year multicenter study of the Cresco implantology concept. Int J Prosthodont. 2003;16:554-562.

27. Tandlich M, Reizman P, Shapira L. The incidence of the marginal bone loss and failure rate of MIS internal hex implants bearing different types of prosthesis. MIS News, 2006;17:2-3.

28. Tandlich M, Ekstein J, Reisman P, Shapira L. Removable prostheses may enhance marginal bone loss around dental implants: A longterm retrospective analysis. J Periodontol. 2007;78:2253-2259.

29. Min-Su B, Dong-Seok S, Mi-Ra A, Hyun-Woo L, Heui-Seung J, ImHee $S$. Retrospective multicenter evaluation of tapered implant with a sandblasted and acid-etched surface at 1 to 4 years of function. Implant Dent. 2011;20:280-284.

30. Weigl P. New prosthetic restorative features of the Ankylos implant system. J Oral Implantol. 2004;30:178-188.

31. Zipprich $\mathrm{H}$, Weigl P, Lange B, Lauer HCh. Erfassung, Ursachen und Folgen von Mikrobewegungen am Implantat-Abutment-Interface. Implantologie, 2007;15:31-46 [in German].

32. Zipprich H. Long-term success: of course?! An investigation of implant-abutment connections. IDENTity, 2006;3:18-19.

33. Arntz Y, Baixe S, Etienne O, Fauxpoint G. Microgap between zirconia abutments and titanium implants. Int $J$ Oral Maxillofac Implants, 2010;25:455-460.

34. Tesmer M, Wallet $\mathrm{S}$, Koutouzis $\mathrm{T}$, Lundgren T. Bacterial colonization of the dental implant fixture-abutment interface: An in vitro study. J Periodontol. 2009;80:1991-1997.

35. Dibart S, Warbington M, Su MF, Skobe Z. In vitro evaluation of the implant-abutment bacterial seal: The locking taper system. Int $J$ Oral Maxillofac Implants, 2005;20:732-737.

36. Piwowarczyk A, Lauer H-Ch, Sorensen JA. Microleakage of various cementing agents for full cast crowns. Dent Mat. 2005;21:445-453.

37. Pieri F, Aldini NN, Marchetti C, Corinaldesi G. Influence of implant-abutment interface design on bone and soft tissue levels around immediately placed and restored single-tooth implants: A randomized controlled clinical trial. Int J Oral Maxillofac Implants, 2011;26: 169-178.

38. Degidi M, Piatelli A, Shibli JA, Perrotti V, lezzi G. Bone formation around a dental implant with a platform switching and another with a TissueCare connection. A histologic and histomorphometric evaluation in man. Titanium, 2009;1:10-17.

39. Bratu EA, Olimpiu K, Radu S. Study of bone level around osseointegrated dental implants. MIS News, 2007;19:2-3.

40. Bratu EA, Tandlich M, Shapira L. A rough surface implant neck with microthreads reduces the amount of marginal bone loss: A prospective clinical study. Clin Oral Implants Res. 2009;20:827-832. 